Article

\title{
Utilization of Grape Seed Extract as a Natural Antioxidant in the Technology of Meat Products Inoculated with a Probiotic Strain of LAB
}

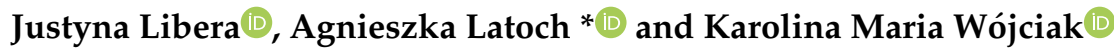 \\ Department of Animal Raw Materials Technology, Faculty of Food Science and Biotechnology, University of Life \\ Sciences in Lublin, Skromna Street 8, 20-704 Lublin, Poland; justyna.libera@up.lublin.pl (J.L.); \\ karolina.wojciak@up.lublin.pl (K.M.W.) \\ * Correspondence: agnieszka.latoch@up.lublin.pl
}

Received: 25 November 2019; Accepted: 16 January 2020; Published: 19 January 2020

\begin{abstract}
Grape seeds have been evaluated for use as food ingredients with stabilizing effects in meat technology. A pork neck, inoculated with probiotic monoculture (Lactobacillus rhamnosus LOCK900), was used as the matrix. The study compared the antioxidant potential of grape seed extract to sodium ascorbate. Three experimental variants of the products were prepared: With grape seed extract, with sodium ascorbate, and without additives. The meat ripened for two months, and during this period of time biophysicochemical analyses (product color, $\mathrm{pH}$, number of lactic acid bacteria, content of free fatty acids, and thiobarbituric acid reactive substances) were carried out. It was found that the extract inhibited lipid hydrolysis occurring in the neck ( $1 \%$ of oleic acid) and limited oxidative processes $\left(0.46 \mathrm{mg} \mathrm{MDA} \mathrm{kg}^{-1}\right)$, with efficacy similar to that of sodium ascorbate $(0.9 \%$ of oleic acid and $0.53 \mathrm{mg}$ MDA kg-1 , respectively). No limitation of the desired lactic acid bacteria growth (approximately $7 \log \mathrm{cfu} \mathrm{g}^{-1}$ ) was noticed in the meat samples with the extract. The results are optimistic because they indicate that not only is it possible to produce fermented pork neck inoculated with probiotic, but there are also no obstacles to utilizing grape seed extract as a natural antioxidant in this technology.
\end{abstract}

Keywords: grape seeds; waste; utilization; antioxidant; dry-cured meat; oxidative stability; probiotic

\section{Introduction}

Grape seeds, which are by-products of juices and wine production, are a rich source of biologically active compounds [1-4]. The seeds account for about $5 \%$ of the weight of the whole grape, representing approximately $40-50 \%$ of solid wastes that different wine industries generate during winemaking process [5]. The polyphenol compounds present in grape seeds can be used as a source of biologically active compounds, mainly antioxidants, in the technology of innovative meat products: Sausages [6-9] and other meats [10-14]. Wine production residues are rich in phenolic compounds $[2,4,15,16]$, and seeds could be a valuable source of antioxidant substances, so it seems necessary to try to reuse this waste. According to Shi and co-workers [17], these compounds are able to trap and quench free radicals, and their antioxidant potentials have been shown to be four to five times higher than that of vitamin C or E. Tang and co-workers [1] noticed that the total flavonoid content in grape seeds is up to ten times higher than grape peel, thus reinforcing the importance of this grape by-product.

The main grape seed phenolic compounds include anthocyanins, flavan-3-ols, flavonols, stilbenes, and phenolic acids [4]. The total phenolic compounds content varies from 55 to $964 \mathrm{mg}$ per $100 \mathrm{~g}$ of grape seeds, the average being $380 \mathrm{mg}$ per $100 \mathrm{~g}$ of dry mass [18]. The average proanthocyanidins content, which is the most important component of grape seeds, is $159 \mathrm{mgg}^{-1}$ of seed [19]. Grape seeds are proanthocyanidins, mainly composed of monomeric catechin and epicatechin, gallic acid, 
and polymeric and oligomeric proanthocyanidins $[8,16]$, which have been demonstrated to be more powerful free radical scavengers than vitamins $C, E$, and $\beta$-carotene [20].

Grape seeds are an interesting alternative to conventional antioxidants in food technology, which is why the meat industry is also beginning to concentrate on the identification and bioactivity evaluation of grape by-products. The results of previously published studies indicate that grape seed extract (GSE) reduced oxidation in both raw and cooked meat, and that when added to pork it did not show significant antimicrobial activity of GSE relative to control [21]. This is an important observation, because it indicates the possibility of using GSE in the technology of fermented meat products with the use of probiotic bacteria. Other studies also indicate that phenolic compounds inhibit the growth of pathogenic bacteria, while they stimulate the growth of probiotics [22,23].

Potentially probiotic dry-fermented neck is a meat product made of a whole muscle running from the neck to the fifth thoracic vertebra of pork, and consists mainly of the muscles of the neck and part of the Longissimus dorsi muscle. The product is manufactured by curing, fermenting, drying, and ripening for at least several months. The neck muscles are a cut out of the pork carcass with a high fat content, which directly affects the palatability of meat products made from them. The quality and stability of dry-fermented neck depends on the course of physicochemical changes during the long time of ripening. As a result of the lipid oxidation, an undesirable, rancid odor and taste, as well as valuable polyunsaturated fatty acids occur in meat and vitamins are lost [16,24]. The microorganisms present in raw meat and starter culture affect the final quality too [25]. To limit the adverse oxidative changes in the dry-fermented meat, it is possible to use the special starter bacteria in the fermentation of meat and substances with antioxidant properties. Among the naturally occurring antioxidants in plants, there are rosemary, sage, thyme, aloe, mustard, etc. [11,14,26].

Lactobacillus rhamnosus LOCK900 strain belongs to a probiotic starter culture, which is used for the fermentation of meat products [27-29]. This monoculture has perfect probiotic properties; it exhibits excellent gastric acid and bile tolerance and has a high stability in foods [30]. However, some research results show that the metabolites produced by these bacteria can accelerate the oxidative changes that occur in the meat product during ripening, ageing, and storage [28,29].

Due to the fact that there are no scientific publications on the problem of using grape seed extract in the process of fermenting pork with probiotic, this study was undertaken to determine the oxidative stability and survival of bacteria in neck inoculated with Lactobacillus rhamnosus LOCK900 probiotic strain.

\section{Materials and Methods}

\subsection{Grape Seed Extract Preparation}

The extract was prepared by the authors, from seeds (post-production waste) obtained from a local wine producer from south-eastern part of Poland. The seeds were washed under a stream of water and dried at $40 \pm 5^{\circ} \mathrm{C}$ for $6 \mathrm{~h}$. Then, $30 \mathrm{~g}$ of seeds, ground in grinder (Ronic Partner, Łódź, Poland), and $200 \mathrm{~mL}$ of $40 \%(v / v)$ ethanol were shaken for $2 \mathrm{~h}$ by a laboratory shaker (Water Bath Shaker Type 357, Elpan, Lubawa, Poland) at $150 \mathrm{rpm}$. The water bath temperature was $50 \pm 10^{\circ} \mathrm{C}$. The slurry was thoroughly separated in an MPW-350R centrifuge (MPW Med. Instruments, Warsaw, Poland) at $5000 \mathrm{~g}$ for $15 \mathrm{~min}$. The supernatant, which remained about $130 \mathrm{~mL}$, was transferred to a round-bottom flask and concentrated in a vacuum evaporator (Rotavapor R-215, Buchi, Flawil, Switzerland) in a water bath at $50-60{ }^{\circ} \mathrm{C}$ and $100-175 \mathrm{hPa}$ pressure. After evaporating $90 \%$ of the solvent, the genuine extract was formed in a final volume of about $13 \mathrm{~mL}$. The extract was then sealed tightly in conical flask placed in the freezer. The grape seed extract was thawed immediately before use.

As a result of this process, $1 \mathrm{~g}$ of extract was obtained from $2.3 \mathrm{~g}$ of raw seeds, so the drug extract ratio (DER genuine) was 2:3. Because the genuine extract had a compact consistency, it was added to the meat in a diluted form (Figure 1). Each extract portion $\left(2 \mathrm{~g} \mathrm{~kg}^{-1}\right.$ meat) was diluted immediately before use with distilled water to a volume of $4 \mathrm{~mL}$. This concentration of GSE was selected as effective, 
based on our own research results that concerned spontaneously fermented meat without the addition of probiotics [31].

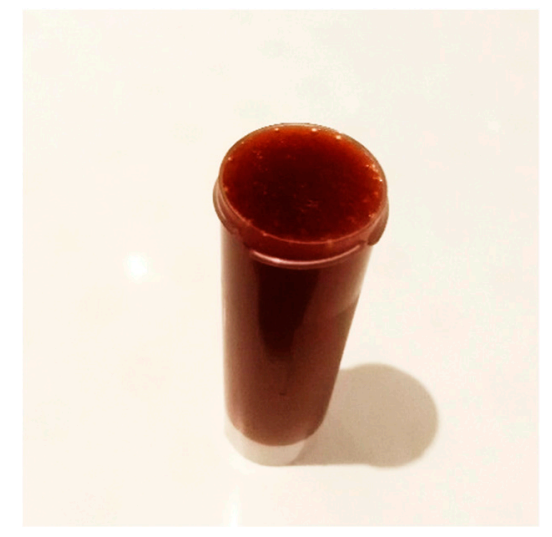

Figure 1. Grape seed extract prepared by authors.

\subsubsection{Color Evaluation of Grape Seed Extract}

The color of an extract was examined using the instrumental method-reflectance (X-Rite Color 8200 spectrophotometer, X-Rite Inc., Grand Rapids, MI, USA). The conditions were $13 \mathrm{~mm}$ port size, illuminant D65 and $10^{\circ}$ standard observer. The X-Rite's white and black standards were used to calibrate the spectrophotometer. To determine the color of the extract, it was previously poured into a clean beaker made of transparent glass, and then a beaker was placed into the measuring gap. Color results were determined in the CIEL $L^{*} a^{*} b^{*}$ scale and lightness $\left(L^{*}\right)$, redness $\left(a^{*}\right)$, and yellowness $\left(b^{*}\right)$ were calculated [32].

\subsubsection{Total Phenolics Contents (TPC) of Grape Seed Extract}

The amount of total phenolics was determined using Folin-Ciocalteau reagent [33]. To $0.5 \mathrm{~mL}$ of the sample, $0.5 \mathrm{~mL}$ of water, $2 \mathrm{~mL}$ Folin-Ciocalteau reagent $\left(1: 5 \mathrm{H}_{2} \mathrm{O}\right)$ were added, and after $3 \mathrm{~min}$, $10 \mathrm{~mL}$ of $10 \% \mathrm{Na}_{2} \mathrm{CO}_{3}$. The contents were mixed and allowed to stand for $30 \mathrm{~min}$. The absorbance at $725 \mathrm{~nm}$ was measured in a UV-Vis spectrophotometer (U-5100 UV-Vis, Hitachi High Technologies America Inc., Schaumburg, IL, USA). A calibration curve was generated using gallic acid as standard. TPC yield was expressed as a milligram of equivalent gallic acid (GAE) per milliliter of extract $\left(\mathrm{mg} \mathrm{GAE} \mathrm{mL}^{-1}\right)$.

\subsubsection{Trolox Equivalent Antioxidant Capacity (TEAC) Assay of Grape Seed Extract}

For measuring the antioxidant potentials of compounds present in the plant extract, the Trolox Equivalent Antioxidant Capacity (TEAC) assay was used [34]. A high TEAC value indicates that the mechanism of antioxidant action of extracts was as a hydrogen donor, and it could terminate the oxidation process by converting free radicals to the stable forms. ABTS radical cation $\left(\mathrm{ABTS}^{+}\right)$was produced by reacting $7 \mathrm{mmol}$ ABTS solution with $2.45 \mathrm{mmol}$ potassium persulphate and allowing the mixture to stand in the dark at room temperature for $12-16 \mathrm{~h}$ before use. The ABTS ${ }^{*+}$ solution was diluted with ethanol to an absorbance of $0.70 \pm 0.02$ at $732 \mathrm{~nm}$. After the addition of $3.9 \mathrm{~mL}$ of diluted ABTS $^{*+}$ solution to $100 \mu \mathrm{L}$ of sample or Trolox standard, the absorbance was measured at exactly $6 \mathrm{~min}$.

\subsection{Probiotic Monoculture Preparation}

Pure cultures of Lb. rhamnosus LOCK900 were obtained from the Pure Culture of the Technical University, Łódź, Poland (strain deposit number: CP005454). The inoculum of bacteria was prepared at the Chair of Food Hygiene and Quality Management (Warsaw University of Life Sciences, Warsaw, Poland) according to the procedure previously described by Neffe-Skocińska et al. [27]. The probiotic 
bacteria count in one milliliter of meat broth at the time of addition to meat was approximately $9.0 \mathrm{log}$ $\mathrm{cfu}$. For the meat fermentation, $2 \mathrm{~mL}$ of probiotic monoculture inoculums per kilogram of meat were used, which was the equivalent of $9.3 \log$ cfu.

\subsection{Manufacture of Dry-Fermented Necks}

The production of dry-fermented pork necks consisted of four stages: Curing and antioxidant adding (stage 1), probiotic inoculation (stage 2), drying and fermentation at $16^{\circ} \mathrm{C}$ for 21 days (stage 3 ), and ripening in vacuum packaging at $4{ }^{\circ} \mathrm{C}$ for 2 months (stage 4). The product was tested three times: After completing stage 3 (before ripening), during stage 4 (after the 1st month of ripening), and after completing stage 4 (after 2 nd month of ripening). Two independent experimental trials were conducted. All determinations were performed in quadruplicate.

The study was carried out on pork meat cuts of Polish White Large breed. Necks (M. longissimus cervicis) were excised at $24 \mathrm{~h}$ post-mortem from half-carcasses chilled at $4{ }^{\circ} \mathrm{C}$. At $72 \mathrm{~h}$ post-mortem, each piece of neck was divided into 3 equal parts (weighing about $1 \mathrm{~kg}$ each) and the meat underwent curing using a surface massage with a curing mixture composed of curing salt (56\%), sea salt $(43 \%)$, and sodium nitrate (1\%). Antioxidant additives were applied together with curing mixture, and then three experimental variants were obtained: GSE-with grape seed extract (at the amount of $2 \mathrm{~g} \mathrm{~kg}^{-1}$ of meat), ASC—with sodium ascorbate (the amount of $1 \mathrm{~g} \mathrm{~kg}^{-1}$ of meat), and CON—without antioxidant added (Table 1).

Table 1. Samples of potentially probiotic dry-fermented pork neck (additives per kg of meat).

\begin{tabular}{cccccc}
\hline Sample & $\begin{array}{c}\text { Curing Salt } \\
(\mathbf{g})\end{array}$ & $\begin{array}{c}\text { Grape Seed } \\
\text { Extract }(\mathbf{g})\end{array}$ & $\begin{array}{c}\text { Sodium } \\
\text { Ascorbate }(\mathrm{g})\end{array}$ & Glucose (g) & $\begin{array}{c}\text { Probiotic } \\
\text { Monoculture (mL) }\end{array}$ \\
\hline GSE & 30 & 2 & - & 12 & $2(9.3 \log \mathrm{cfu})$ \\
ASC & 30 & - & 1 & 12 & $2(9.3 \log \mathrm{cfu})$ \\
CON & 30 & - & - & 12 & $2(9.3 \log \mathrm{cfu})$ \\
\hline
\end{tabular}

Explanatory notes: GSE-neck with grape seed extract; ASC—neck with sodium ascorbate; CON—neck without antioxidant.

Specified amounts of grape seed extract and sodium ascorbate were diluted in $4 \mathrm{~mL}$ of distilled water and additives were applied by rubbing them into the meat surface for about $3 \mathrm{~min}$. Subsequently, all batches were placed in a refrigerator at $0 \pm 1^{\circ} \mathrm{C}$ for $72 \mathrm{~h}$ to allow the additives to diffuse. After curing, each piece was rubbed with glucose in the form of powder. Next, the probiotic starter monoculture (Lb. rhamnosus LOCK900) was applied; for this purpose, an automatic pipette equipped with sterile disposable tips was used. A measured quantity of inoculums $-2 \mathrm{~mL}(9.3 \log \mathrm{cfu}) \mathrm{kg}^{-1}$ — was rubbed by hand into the meat. After that, the neck portions were hung (Figure 2, top) in a fermentation chamber under controlled conditions for 21 days. The conditions were: Temperature of $16 \pm 1{ }^{\circ} \mathrm{C}$, relative humidity $75 \pm 5 \%$, and air flow rate $0.05 \mathrm{~m} \mathrm{~s}^{-1}$ (30\% of air circulation). Following fermentation and drying, the necks (weighing about $0.7 \mathrm{~kg}$ each) were individually vacuum-packed into polyethylene barrier bags and after that they ripened in a storage chamber at $4 \pm 1{ }^{\circ} \mathrm{C}$ for 2 months. Figure 2 (below) shows the cross-sectional appearance of ready dry-fermented pork neck after ripening for 2 months. 


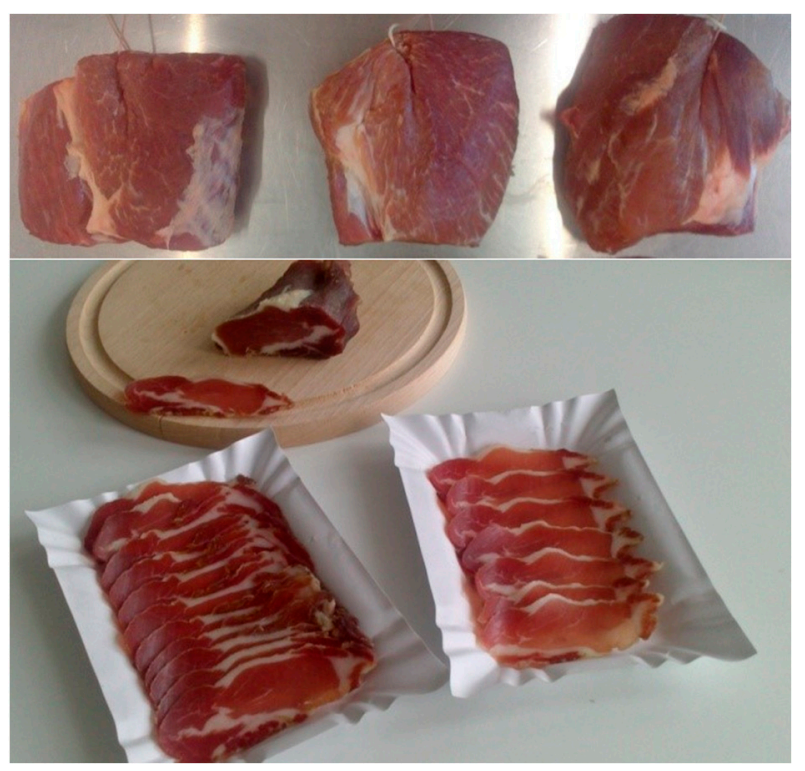

Figure 2. Dry-fermented pork neck: Before fermentation and ripening (top) and after two months of ripening (bottom).

\subsection{Microbiological Characteristics of Dry-Fermented Neck}

\subsubsection{Lactic Acids Bacteria (LAB) and Enterobacteriaceae (ENT) Counts of Meat Product}

The measurements of the number of lactic acid bacteria-including probiotic bacteria and Enterobacteriaceae-were performed, and the counts were expressed as colony forming units (cfu) in grams. Samples for the microbiological analyses have been taken as a cross-section from the middle of the neck being tested. Microbiological analyses were carried out at AGROLAB Laboratory (Deblin, Poland) according to ISO 15214 [35] and ISO 21528-2 [36].

\subsection{2. $\mathrm{pH}$ Value of Dry-Fermented Meat Product}

The $\mathrm{pH}$ value was measured in a filtrate by mixing $10 \mathrm{~g}$ of minced sample with $100 \mathrm{~mL}$ of distilled water for $1 \mathrm{~min}$, using a dispenser (T25 Basic Ultra-Turrax, IKA, Staufen, Germany). The $\mathrm{pH}$ was measured with a digital pH-meter CPC-501 (Elmetron, Zabrze, Poland) equipped with a pH electrode (ERH-111, Hydromet, Gliwice, Poland). The $\mathrm{pH}$ readings were recorded at exactly 4 min after the insertion of the electrode into the sample. The $\mathrm{pH}$-meter was standardized with buffer solutions at $\mathrm{pH}$ 4.0, 7.0, and 9.0 [37].

\subsection{Assessment of Oxidative Stability of Dry-Fermented Neck}

\subsubsection{Free Fatty Acids (FFA) of Meat Product}

The free fatty acids (FFA) of the meat product were determined using a previously described method [38] with some modifications [39]. Exactly $10 \mathrm{~g}$ of ground meat sample was blended for $2 \mathrm{~min}$ with $60 \mathrm{~mL}$ of chloroform in the presence of about $10 \mathrm{~g}$ of anhydrous sodium sulphate. Next, it was filtered through Whatman no.1 filter paper. Twenty $\mathrm{mL}$ of chloroform extract was dried in an SPU-200 oven (ZUT Colector, Cracow, Poland) to determine the fat weight. Another $20 \mathrm{~mL}$ extract was taken into a $150 \mathrm{~mL}$ conical flask. About 4 drops of $0.2 \%$ phenolphthalein indicator was added to the chloroform extract, which was titrated against potassium hydroxide solution $\left(0.1 \mathrm{~mol} \mathrm{~L}^{-1}\right.$ in $96 \%$ 
ethanol) to get the pink color end point. The quantity of potassium hydroxide consumed during the titration was recorded. FFA as percentage of oleic acid was calculated as follows:

$$
\text { FFA }(\% \text { of oleic acid })=\frac{0.1 \cdot 0.1 \mathrm{~mol} \mathrm{KOH}(\mathrm{mL}) \cdot 0.282}{\text { weight of fat }(\mathrm{g})} \cdot 100
$$

\subsubsection{Thiobarbituric Acid Reactive Substances (TBArs) of Meat Product}

TBArs were determined as in the method described by Pikul et al. [40], with slight modifications. Exactly $4 \mathrm{~g}$ of ground meat sample was blended for $1 \mathrm{~min}$ with $12 \mathrm{~mL}$ of cold perchloric acid $(4 \%)$ in the presence of $200 \mu \mathrm{L}$ of butylated hydroxytoluene solution $(0.01 \%$ in ethanol). Then, it was filtered through Whatman no.1 filter paper. Subsequently, $650 \mu \mathrm{L}$ of filtrate and 2-thiobarbituric acid solution $\left(0.02 \mathrm{~mol} \mathrm{~L}^{-1}\right.$ in distilled water) were mixed. A mixture of $650 \mu \mathrm{L}$ of $4 \%$ cold perchloric acid and $650 \mu \mathrm{L}$ of TBA solution was used as the reference sample. The heating part of the experiment was performed for $20 \mathrm{~min}$ at $100{ }^{\circ} \mathrm{C}$. Then, spectrophotometrically (U-5100 UV-Vis, Hitachi High Technologies America Inc., Schaumburg, IL, USA) the absorbance at $532 \mathrm{~nm}$ was measured. The TBArs value as $\mathrm{mg}$ malondialdehyde per $\mathrm{kg}$ was calculated as follows:

$$
\text { TBArs }\left(\mathrm{mg} \mathrm{MDA} \mathrm{kg}^{-1}\right)=5.5 \cdot \text { Absorbance at } 532 \mathrm{~nm}
$$

\subsection{Color Evaluation of Meat Product}

The color of dry-fermented neck was measured using an X-Rite Color 8200 spectrophotometer (X-Rite Inc., Grand Rapids, MI, USA) [32]. Color measurements were performed at room temperature at six different locations of neck slices. For the meat product, the measurements were made on a freshly cut surface of $10 \mathrm{~mm}$ thick slices. The total color difference $\left(\Delta E^{*}\right)$ was calculated based on $\Delta L^{*}, \Delta a^{*}$ and $\Delta b^{*}$ results for each sample according to the time of ripening, as follows:

$$
\Delta E^{*}=\left(\left(\Delta L^{*}\right)^{2}+\left(\Delta a^{*}\right)^{2}+\left(\Delta b^{*}\right)^{2}\right)^{1 / 2}
$$

\subsection{Statistical Analysis}

For the statistical analysis, the collected data were analyzed by a two-way analysis of variance (ANOVA). The effect of added antioxidant and storage time on changes in selected physicochemical parameters was taken into account. The experiment was realized in four repeats in each of the replications. Calculations were made using Microsoft Office Excel 2007 (Microsoft Corporation, Redmond, WA, USA) and Statistica 10 (StatSoft, Warsaw, Poland) software. The normality of distribution of the variables within groups was verified with the Shapiro-Wilk test, and the Levene's test was used to assess the equality of variances for a variable calculated for the groups. All the groups show the normality of distribution of the variables at $p>0.05$. Next, the post hoc Tukey's procedure was used to find patterns and relationships between subgroups. Differences among groups were determined as statistically significant at a level of $p \leq 0.05$. All the results are expressed as means \pm standard deviation.

\section{Results and Discussion}

\subsection{Grape Seed Extract Characterization}

An extract obtained by the authors was subjected to screening for its stability of color. The total color difference $\left(\Delta E^{*}\right)$ was calculated from the difference of parameters before and after the sunlight exposure. The stability of color was determined for each sample according to the equation:

$$
\Delta E^{*}=\left(\left(\Delta L^{*}\right)^{2}+\left(\Delta a^{*}\right)^{2}+\left(\Delta b^{*}\right)^{2}\right)^{1 / 2}
$$

where: $\Delta L^{*}, \Delta a^{*}$ and $\Delta b^{*}$ are changes between values over time. The obtained values $\left(\Delta L^{*}=0.6\right.$; $\Delta a^{*}=0.02$ and $\left.\Delta b^{*}=0.1\right)$ indicate a very permanent color of the extract when in contact with 
sunlight (Table 2). It was ascertained that the colour of the applied extract was yellow-orange and looked just like buckwheat honey.

Table 2. Color and antioxidant properties of grape seed extract (mean \pm standard deviation).

\begin{tabular}{|c|c|}
\hline Tests & Grape Seed Extract \\
\hline \multicolumn{2}{|c|}{ Color parameters of extract: } \\
\hline CIEL $L^{*}$ & $27.7 \pm 0.5$ \\
\hline $\mathrm{CIE} a^{*}$ & $0.75 \pm 0.3$ \\
\hline $\mathrm{CIE} b^{*}$ & $11.2 \pm 0.2$ \\
\hline$\Delta E^{*}$ during exposure to light & 0.61 \\
\hline \multicolumn{2}{|c|}{ Antioxidant properties of extract: } \\
\hline TEAC Assay (mmol TE of $\mathrm{mL}^{-1}$ ) & $5.14 \pm 0.8$ \\
\hline TPC Assay (mg GAE mL $\left.{ }^{-1}\right)$ & $6.74 \pm 0.2$ \\
\hline
\end{tabular}

Explanatory notes: $\mathrm{CIEL} L^{*}$-lightness; $\mathrm{CIE} a^{*}$-redness; $\mathrm{CIE} b^{*}$-yellowness; $\Delta E^{*}$-total color difference; TEAC—Trolox Equivalent Antioxidant Capacity; TPC—Total Phenolics Content.

For measuring the potential antioxidant properties of the extract, the TPC and TEAC assays were used. It is known that the antioxidant capacity of food is strongly correlated with free phenolic content. The test showed that the extract prepared by the authors, possessed free radical-scavenging activity (Table 2). The TPC values obtained for the statement differ from the results of other authors. The results of papers by other authors showed that there could be about 100 times more total polyphenols compound in a commercial, lyophilized preparation from grape seed [21]. This discrepancy is probably due to the way we obtained the extract. The extract prepared by the authors was concentrated in a vacuum evaporator and then not freeze-dried, because the goal was to prepare the extract as simply as possible. Grape seed extract prepared by concentrating (but without freeze-drying) can be more likely used in meat technology because meat factories are not equipped with lyophilizers as standard.

\section{2. $p H$ Value, LAB, and Enterobacteriaceae Counts of Dry-Fermented Neck}

The use of grape seeds in the meat technology with the addition of probiotic bacteria is not easy. A strategy should be planned in the production process that would allow the probiotics to grow in the meat matrix. The reformulation of the recipe, consisting of replacing sodium ascorbate with a plant extract, can lead to the inhibition of the development of beneficial microorganisms, which in turn can lead to beneficial, but also undesirable changes in the final product.

Grape seed extract has antioxidant and antimicrobial activity [22,23,41,42]. Antibacterial effects of the flavonoids and phenolics extracted from grape seeds are reported in literature [42-44]. The results showed that grape extract can limit the development of several pathogens, including: Staphylococcus aureus, Bacillus subtilis, Psudomonas aeruginosa, Escherichia coli, Enterococcus faecalis Streptococcus pyogenes, Campylobacter spp., etc.

The addition of plant material in meat technology can limit or eliminate the development of saprophytic or pathogenic bacteria, but it can also inhibit the development of probiotics in the product and change the direction of biophysicochemical changes. In the case of raw-fermented ripening meats-the technology of which uses a hurdle method-some uncontrolled changes in the direction of ripening may threaten product safety.

The number of lactic acid bacteria in the product, and thus its $\mathrm{pH}$ value, indicates the evolution of fermentation. In the experiment, no unfavorable effect of the extract applied on the neck $\mathrm{pH}$ was found (Table 3). In all variants (GSE, ASC, CON), values were similar (5.4-5.8) and did not differ significantly $(p \leq 0.05)$. During storage, the $\mathrm{pH}$ value of meat products was reduced by about $5 \%$ and this was a significant change $(p \leq 0.05)$. The increase in product acidity was due to the starter culture activity. Probiotic strain Lb. rhamnosus LOCK900 used for fermenting the pork neck, produces significant amounts of organic acids modifying the $\mathrm{pH}$ of the meat product. In the experiment, the LAB 
number was approximately $5.7 \log$ cfu g $^{-1}$ before ripening, and 6.7-7.2 log cfu $\mathrm{g}^{-1}$ after ripening, with no significant differences $(p \leq 0.05)$ between the test variants (GSE vs. ASC vs. CON). During ripening, a different LAB number was observed between the ASC sample (6.4 log cfu $\left.\mathrm{g}^{-1}\right)$ and GSE sample $\left(6.9 \log \mathrm{cfu} \mathrm{g}^{-1}\right)$, but these differences were not significant $(p>0.05)$. The results indicate that the grape seed extract used in the technology did not work anti-bacterially against the lactobacilli. Interestingly, the authors found that this extract limited the growth of Enterobacteriaceae. Before ripening, the GSE neck was found to have a significantly lower (by two logarithmic) number of these bacteria than the other samples. In addition, during the ripening process, the number of Enterobacteriaceae in the GSE neck decreased even further $\left(<1.00 \mathrm{log} \mathrm{cfu} \mathrm{g}^{-1}\right)$. During two months of ripening in stored chambers at $4{ }^{\circ} \mathrm{C}$, the number of Enterobacteriaceae was reduced in all samples.

Table 3. Lactic acid bacteria and Enterobacteriaceae counts $\left(\log \mathrm{cfu}^{-1}\right), \mathrm{pH}$ values of dry-fermented pork neck (mean \pm standard deviation).

\begin{tabular}{ccccc}
\hline & Sample & Before Ripening & During Ripening & After Ripening \\
\hline \multirow{3}{*}{ Lactic acid bacteria } & GSE & $5.71 \pm 0.30^{\mathrm{aA}}$ & $6.88 \pm 0.28^{\mathrm{aB}}$ & $6.93 \pm 0.31^{\mathrm{aB}}$ \\
& ASC & $5.69 \pm 0.29^{\mathrm{aA}}$ & $6.38 \pm 0.28^{\mathrm{aB}}$ & $6.67 \pm 0.29^{\mathrm{aB}}$ \\
& CON & $5.81 \pm 0.31^{\mathrm{aA}}$ & $6.52 \pm 0.26^{\mathrm{aB}}$ & $7.15 \pm 0.27^{\mathrm{aC}}$ \\
\hline \multirow{3}{*}{ Enterobacteriaceae } & GSE & $2.75 \pm 0.30^{\mathrm{bA}}$ & $<1.00 \pm 0.00^{\mathrm{bB}}$ & $<1.00 \pm 0.00^{\mathrm{bB}}$ \\
& ASC & $5.32 \pm 0.29^{\mathrm{aA}}$ & $3.64 \pm 0.25^{\mathrm{aB}}$ & $1.99 \pm 0.29^{\mathrm{aC}}$ \\
& CON & $4.89 \pm 0.30^{\mathrm{aA}}$ & $3.94 \pm 0.24^{\mathrm{aB}}$ & $2.23 \pm 0.26^{\mathrm{aC}}$ \\
\hline \multirow{2}{*}{ pH value } & GSE & $5.75 \pm 0.06^{\mathrm{aA}}$ & $5.50 \pm 0.07^{\mathrm{aB}}$ & $5.45 \pm 0.05^{\mathrm{aB}}$ \\
& ASC & $5.66 \pm 0.09^{\mathrm{aA}}$ & $5.42 \pm 0.08^{\mathrm{aB}}$ & $5.40 \pm 0.06^{\mathrm{aB}}$ \\
& CON & $5.73 \pm 0.11^{\mathrm{aA}}$ & $5.47 \pm 0.05^{\mathrm{aB}}$ & $5.41 \pm 0.07^{\mathrm{aB}}$ \\
\hline
\end{tabular}

Explanatory notes: GSE—neck with grape seed extract; ASC—neck with sodium ascorbate; CON—neck without antioxidant; ${ }^{a, b}$ within each column (sample), means followed by a common lowercase letter are not significantly different $(p>0.05)$; ${ }^{A-C}$ within each row (ripening time), means followed by a common capital letter are not significantly different $(p>0.05)$.

Wójciak et al. [28] found that after the completion of fermentation with probiotic Lb. rhamnosus, the $\mathrm{pH}$ of the meat product was similar to that recorded in our study (5.62). They recorded a significantly higher logarithm of LAB-almost two orders-in the pork neck fermented using the same probiotic. Significantly higher $\mathrm{pH}$ values were found by other researchers. Wang et al. [13] found that in the matured GSE bacon, the $\mathrm{pH}$ was 6.14 after three weeks of storage, and immediately after ripening, it was higher than 6.23. Interestingly, in the control sample without antioxidant, the $\mathrm{pH}$ was even higher, reaching 6.56 after maturation and 6.37 after storage. Much lower (about 4.5) pH values were noted in the Czech sausage Polican after the end of the 21-day fermentation [6]. High acidity referred to both samples with grape seed extract and control ones. Results of microbial analysis of the pork neck in this study were similar to the acidity results. All samples showed an increase in lactic acid bacteria during storage of the meat product under restricted air access.

\subsection{Oxidative Stability of Dry-Fermented Neck}

Bacterial starter cultures used in the meat fermentation process may exhibit different effects. Ruiz-Moyano et al. [25] have shown that some starter cultures can increase the oxidative stability of the ripening sausage, while others can reduce it. In the experiment described in this work, an Lb. rhamnosus LOCK900 probiotic culture was used for fermentation because it is a good starter due to its resistance to conditions in the digestive tract [30]; however, it may have a prooxidative effect in pork meat products during long-term ripening $[27,28]$. The oxidation process has progressed in all samples over time. There was a statistically significant $(p \leq 0.05)$ effect of the addition of grape seed extract on lipid hydrolysis inhibition (Table 4). 
Table 4. Free fatty acid (\% of oleic acid), TBA-reactive substances $\left(\mathrm{mg} \mathrm{kg}^{-1}\right)$ of dry-fermented pork neck (mean \pm standard deviation).

\begin{tabular}{ccccc}
\hline & Sample & Before Ripening & During Ripening & After Ripening \\
\hline \multirow{4}{*}{ FFA } & GSE & $0.43 \pm 0.03^{\mathrm{bA}}$ & $0.68 \pm 0.03^{\mathrm{bB}}$ & $0.96 \pm 0.05^{\mathrm{bC}}$ \\
& ASC & $0.41 \pm 0.03^{\mathrm{bA}}$ & $0.65 \pm 0.05^{\mathrm{bB}}$ & $0.93 \pm 0.05^{\mathrm{bB}}$ \\
& CON & $0.55 \pm 0.04^{\mathrm{aA}}$ & $1.03 \pm 0.04^{\mathrm{aB}}$ & $1.49 \pm 0.03^{\mathrm{aC}}$ \\
\hline \multirow{3}{*}{ TBArs } & GSE & $0.31 \pm 0.03^{\mathrm{aA}}$ & $0.36 \pm 0.04^{\mathrm{bA}}$ & $0.46 \pm 0.05^{\mathrm{bB}}$ \\
& ASC & $0.29 \pm 0.05^{\mathrm{aA}}$ & $0.34 \pm 0.05^{\mathrm{bA}}$ & $0.53 \pm 0.04^{\mathrm{bB}}$ \\
& CON & $0.37 \pm 0.04^{\mathrm{aA}}$ & $0.57 \pm 0.05^{\mathrm{aB}}$ & $0.72 \pm 0.05^{\mathrm{aC}}$ \\
\hline
\end{tabular}

Explanatory notes: GSE—neck with grape seed extract; ASC—neck with sodium ascorbate; CON—neck without antioxidant; a,b within each column (sample), means followed by a common lowercase letter are not significantly different $(p>0.05)$; ${ }^{\text {A-C }}$ within each row (ripening time), means followed by a common capital letter are not significantly different $(p>0.05)$.

In the GSE sample, a lower concentration of free fatty acids (FFA) was found, which was similar to that obtained in the ASC sample. Immediately after production, the free fatty acid content in GSE and ASC samples was $24 \%$ lower and $36 \%$ lower after storage as compared to the CON sample. The results show the effective reducing properties of antioxidants found in this grape seed extract. The ripening pork neck produced with antioxidant additives (GSE and ASC) was characterized by increased oxidative stability during storage as compared to the $\mathrm{CON}$ one. Both antioxidants inhibited unfavorable fat metabolisms with similar efficacy. Immediately following the production, the samples GSE and ASC revealed the concentration of compounds reacting with 2-thiobarbituric acid to be lower by approximately $19 \%$ than those in the CON sample. During the two-month ripening in storage chamber, a 31-39\% difference in the TBArs index was found between samples containing the antioxidant additive and the control sample. The TBArs value after the complete ripening of the potentially probiotic neck with the grape seed extract addition was lower than the ASC sample. These results suggest that grape seed extract can be used as an ascorbate substitute to delay the formation of secondary oxidation products. Wang et al. [13] noticed a similar (0.38 $\mathrm{mg}$ MDA kg-1) TBArs index in dry-fermented bacon with a grape seed extract addition. Very similar results have been described by Lorenzo et al. [7], who have used grape seed extract in chorizo production. The addition of the extract affected the reduction of the amount of secondary fat oxidation products. On the other hand, in the control sample, as in the present experiment, about $0.78 \mathrm{mg} \mathrm{MDA} \mathrm{kg}^{-1}$ was recorded by those authors following the storage of the meat product. Other authors reported similar values of the TBArs of the control sample and in the samples with the addition of grape seed extract of different concentrations $[9,12,21]$.

\subsection{Color Evaluation of Dry-Fermented Neck}

The addition of grape seed extract (GSE) had no negative effect on the color change of meat products during the first two study periods (Table 5). Studies carried out after a two-month ripening time showed differences between tests containing antioxidant additives. In the GSE and ASC samples, the lightness of the meat product was found to be about $11 \%$ higher than in the control sample after the completion of the production stages. This parameter was significantly modified by the ripening period and decreased over time. The lightness of ripening neck produced without the antioxidant $(\mathrm{CON})$ was changed by about $24 \%$ during its time being kept in the storage chamber when compared to the values obtained previously.

The GSE sample was found to be redder than the others (10.3 vs. 9.2), which was a significant difference $(p \leq 0.05)$ (Table 5). Lowering the CIEL* value while increasing the CIE $a^{*}$ denotes a change in the color of the meat product to dark red or brown. In this sample, the change of this parameter along with the length of processing time was also noted. In the remaining samples (ASK and CON), no change in the CIE $a^{*}$ parameter was observed over time, while in the sample with the extract, an increase by $28 \%$ of this parameter was noted. These results indicate the antioxidant effect of the 
extract. It stabilizes the color of the product by inhibiting the conversion of red myoglobin to brown metmyoglobin. The applied supplements and ripening duration did not modify the CIE $b^{*}$ parameter (Table 5). The yellow color component of meat products ranged from 11.1 to 13.0.

Table 5. Color parameters of dry-fermented pork neck (mean \pm standard deviation).

\begin{tabular}{ccccc}
\hline Sample & & Before Ripening & During Ripening & After Ripening \\
\hline \multirow{2}{*}{${\text { CIE } L^{*}}^{*}$} & GSE & $48.63 \pm 1.55^{\mathrm{bA}}$ & $44.42 \pm 1.46^{\mathrm{aB}}$ & $44.19 \pm 1.69^{\mathrm{aB}}$ \\
& ASC & $51.35 \pm 2.40^{\mathrm{aA}}$ & $45.00 \pm 1.87^{\mathrm{aB}}$ & $45.63 \pm 1.71^{\mathrm{aB}}$ \\
& CON & $52.57 \pm 1.46^{\mathrm{aA}}$ & $43.15 \pm 2.06^{\mathrm{aB}}$ & $40.01 \pm 1.46^{\mathrm{aB}}$ \\
\hline \multirow{2}{*}{$\mathrm{CIE} a^{*}$} & GSE & $10.26 \pm 0.50^{\mathrm{aA}}$ & $12.33 \pm 0.66^{\mathrm{aB}}$ & $13.36 \pm 0.68^{\mathrm{aB}}$ \\
& ASC & $9.18 \pm 0.57^{\mathrm{bA}}$ & $10.28 \pm 0.82^{\mathrm{bA}}$ & $11.08 \pm 0.68^{\mathrm{bA}}$ \\
& CON & $9.18 \pm 0.55^{\mathrm{bA}}$ & $10.27 \pm 0.85^{\mathrm{bA}}$ & $11.73 \pm 0.53^{\mathrm{bA}}$ \\
\hline \multirow{3}{*}{$\mathrm{CIE} b^{*}$} & GSE & $11.67 \pm 1.08^{\mathrm{aA}}$ & $12.11 \pm 0.93^{\mathrm{aA}}$ & $12.32 \pm 0.92^{\mathrm{aA}}$ \\
& ASC & $12.96 \pm 0.88^{\mathrm{aA}}$ & $12.78 \pm 0.82^{\mathrm{aA}}$ & $12.14 \pm 0.98^{\mathrm{aA}}$ \\
& CON & $11.48 \pm 0.67^{\mathrm{aA}}$ & $11.92 \pm 0.60^{\mathrm{aA}}$ & $11.13 \pm 0.65^{\mathrm{aA}}$
\end{tabular}

Explanatory notes: GSE—neck with grape seed extract; ASC—neck with sodium ascorbate; CON—neck without antioxidant; CIEL - lightness; $\mathrm{CIE} a^{*}$-redness; CIE $b^{*}$-yellowness; ${ }^{\mathrm{a}, \mathrm{b}}$ within each column (sample), means followed by a common lowercase letter are not significantly different $(p>0.05)$; ${ }^{A}, \mathrm{~B}$ within each row (ripening time), means followed by a common capital letter are not significantly different $(p>0.05)$.

Analysis of the total color change $\left(\Delta E^{*}\right)$ of the meat product during ripening showed that the color of the control neck was the least stable (Table 6). The $\Delta E^{*}$ of this variant during the first month of ripening was 9.5 units, indicating a large deviation of color from the standard that had the pork neck immediately after production. In the next month, the total color change was 3.6 units, which also indicates a significant deviation from the color of the product after the first month of ripening. In total, the color of control sample changed by as much as 12 units throughout the entire ripening process.

Table 6. Total difference of color of dry-fermented pork neck.

\begin{tabular}{cccc}
\hline & Before Ripening (Time 0) & During Ripening (Time 1) & After Ripening (Time 2) \\
\hline$\Delta E^{*}$ GSE-ASC & 3.20 & 2.23 & 2.70 \\
$\Delta E^{*}$ GSE-CON & 4.09 & 2.43 & 4.64 \\
$\Delta E^{*}$ ASC-CON & 1.92 & 2.04 & 5.75 \\
\hline & GSE & ASC & CON \\
\hline$\Delta E^{*}$ time 1-time 0 & 4.71 & 6.45 & 9.49 \\
$\Delta E^{*}$ time 2-time 0 & 5.45 & 6.08 & 12.82 \\
$\Delta E^{*}{ }_{\text {time 2-time 1 }}$ & 1.08 & 1.20 & 3.55 \\
\hline
\end{tabular}

Explanatory notes: GSE—neck with grape seed extract; ASC—neck with sodium ascorbate; CON—neck without antioxidant; $\Delta E^{*}$ samples -total difference of color between the samples; $\Delta E^{*}$ time - total difference of color over time periods.

In the GSE sample, the total color change was the smallest, both after the first (4.7 units) and after the second (1.1 unit) month. These values indicate average color deviations. However, the total color change during the entire maturing process for the GSE sample was close to the value of the ASC sample (5.5 vs. 6.1 units). Other authors have also noticed a change in the color of matured meat product depending on time. Other authors [7] recorded the dependence observed in this experiment for higher values of the $\mathrm{CIE} a^{*}$ parameter in the GSE additive sample. On the 50th day of the experiment, they noticed that the chorizo red color parameter with GSE addition was about three units higher as compared to the control sample. On the other hand, the yellow chromaticity and the color lightness $\left(\mathrm{CIEL}^{*}\right)$ was higher by five units.

In our experiment, we compared the differences in the total color of the potentially probiotic neck, depending on the antioxidant supplement used. The sample with the extract had a different (3.2-4.1 units) total color than the other samples, before the ripening period. However, this test had the 
most durable color during processing. After the complete ripening process, the changes between the samples were as follows: Samples GSE and ASC were similar (2.7 units), samples CON and others were different by $4.6-5.8$ units.

\section{Conclusions}

It was found that the dry-fermented pork necks inoculated with probiotic strain, which ripened for two months, were characterized by the appropriate biophysicochemical parameters. The use of each of the proposed antioxidant substances improved the oxidative stability of the neck, and the use of a plant-derived additive did not negatively affect the characteristics of the product and the direction of its changes during processing. The addition of grape seed extract effectively inhibits the lipid hydrolysis processes in the dry-fermented pork neck, reducing the free fatty acid content after two months of ripening in storage chamber at $4{ }^{\circ} \mathrm{C}$. The grape seed extract, with efficacy similar to sodium ascorbate, counteracts unfavorable oxidative changes in the neck during processing stages. The results indicate that the addition of grape seed extract did not limit the development of the number of lactic acid bacteria in the meat product. Therefore, it is possible to grow probiotic bacteria in dry-fermented necks as a matrix. The utilization of grape seed extract also had a positive effect on inhibiting the number of Enterobacteriaceae in the product, and finally on eliminating them from the product. It was also found that the addition of grape seed extract to the dry-fermented pork neck had a positive effect on the color of the product. The color of the cross-section was redder compared to the other test variants, and the total color change of the product during storage was the smallest. The results of the experiment show that it is possible to create an innovative functional meat product using waste, which is part of the 'no waste' trend. The utilization of by-products and waste, and the use of them as a source of new raw materials in meat technology, allows the design of a new meat product with probiotic properties which is, thus, a functional food. The obtained research results are promising; moreover, they give hope for the use of other strains of probiotic bacteria for the fermentation of rarely used raw meat materials, i.e., pork neck.

Author Contributions: Conceptualization, J.L.; Methodology, J.L.; Software, A.L.; Validation, K.M.W.; Formal Analysis, A.L. and K.M.W.; Investigation, J.L.; Resources, A.L; Data A.L. and J.L.; Writing-Original Draft Preparation, J.L.; Writing-Review \& Editing, A.L.; Visualization, A.L. and J.L.; Supervision, J.L.; Project Administration, A.L. and J.L.; Funding Acquisition, K.M.W. All authors have read and agreed to the published version of the manuscript.

Funding: This research received no external funding.

Acknowledgments: The authors sincerely thank D. Kołożyn-Krajewska, Head of the Chair of Food Hygiene and Quality Management in Warsaw University of Life Sciences for preparing the starter cultures of a Lactobacillus rhamnosus LOCK900 strain.

Conflicts of Interest: The authors declare no conflict of interest.

\section{References}

1. Tang, G.-Y.; Zhao, C.-N.; Liu, Q.; Feng, X.-L.; Xu, X.-Y.; Cao, S.-Y.; Meng, X.; Li, S.; Gan, R.-Y.; Li, H.-B. Potential of grape wastes as a natural source of bioactive compounds. Molecules 2018, 23, 2598. [CrossRef]

2. Maier, T.; Schiebe, A.; Kammerer, D.R.; Carle, R. Residues of grape (Vitis vinifera L.) seed oil production as a valuable source of phenolic antioxidants. Food Chem. 2009, 112, 551-559. [CrossRef]

3. Pellegrini, N.; Serafini, M.; Colombi, B.; Del Rio, D.; Salvatore, S.; Bianchi, M.; Brighenti, F. Total antioxidant capacity of plant foods, beverages and oils consumed in Italy assessed by three different in vitro assays. J. Nutr. 2003, 133, 2812-2819. [CrossRef]

4. Machado, N.F.L.; Domínguez-Perles, R. Addressing facts and gaps in the phenolics chemistry of winery by-products. Molecules 2017, 22, 286. [CrossRef]

5. Brenes, A.; Viveros, A.; Chamorro, S.; Arija, I. Use of polyphenol-rich grape byproducts in monogastric nutrition. A review. Anim. Feed Sci. Technol. 2016, 211, 1-17. [CrossRef]

6. Salakova, A.; Pavlik, Z.; Kamenik, J.; Cech, Z.; Steinhauserova, I. The use of extract from blue grapes in the manufacturing of dry sausages. Maso Int. 2012, 1, 39-43. 
7. Lorenzo, J.M.; Gonzalez-Rodriquez, R.M.; Sanchez, M.; Amado, I.R.; Franco, D. Effects of natural (grape seed and chestnut extract) and synthetic antioxidants (buthylated hydroxytoluene, BHT) on physical, chemical, microbiological and sensory characteristic of dry cured sausage "chorizo". Food Res. Int. 2013, 54, 611-620. [CrossRef]

8. Ribas-Agusti, A.; Gratacos-Cubarsi, M.; Sarraga, C.; Guardia, M.D.; Garcia-Regueiro, J.A.; Castellari, M. Stability of phenolic compounds in dry fermented sausages added with cocoa and grape seed extracts. LWT Food Sci. Technol. 2014, 57, 329-336. [CrossRef]

9. Kulkarni, S.; De Santos, F.A.; Kattamuri, S.; Rossi, S.J.; Brewer, M.S. Effect of grape seed extract on oxidative, color and sensory stability of a pre-cooked, frozen, re-heated beef sausage model system. Meat Sci. 2011, 88, 139-144. [CrossRef]

10. Reddy, G.V.; Sen, A.R.; Nair, P.N.; Reddy, K.S.; Reddy, K.K.; Kondaiah, N. Effects of grape seed extract on the oxidative and microbial stability of restructured mutton slices. Meat Sci. 2013, 95, 288-294. [CrossRef]

11. Banon, S.; Diaz, P.; Rodriguez, M.; Garrido, M.D.; Price, A. Ascorbate, green tea and grape seed extracts increase the shelf life of low sulphite beef patties. Meat Sci. 2007, 77, 626-633. [CrossRef] [PubMed]

12. Price, A.; Diaz, P.; Banon, S.; Garrido, M.D. Natural extracts versus sodium ascorbate to extend the shelf life of meat-based ready-to-eat meals. Food Sci. Technol. Int. 2013, 19, 427-438. [CrossRef] [PubMed]

13. Wang, Y.; Li, F.; Zhuang, H.; Chen, X.; Li, L.; Chen, X.; Zhang, J. Effects of plant polyphenols and $\alpha$-tocopherol on lipid oxidation, residual nitrites, biogenic amines, and N-nitrosamines formation during ripening and storage of dry-fermented bacon. LWT Food Sci. Technol. 2015, 60, 199-206. [CrossRef]

14. Kumar, Y.; Yadav, D.N.; Ahmad, T.; Narsaiah, K. Recent trends in the use of natural antioxidants for meat and meat products. Compr. Rev. Food Sci. Food Saf. 2015, 14, 796-812. [CrossRef]

15. Garcia-Lomillo, J.; Gonzalez-San Jose, M.L. Applications of wine pomace in the food industry: Approaches and functions. Compr. Rev. Food Sci. Food Saf. 2017, 16, 3-22. [CrossRef]

16. Bagchi, D.; Bagchi, M.; Stohs, S.J.; Das, D.K.; Ray, S.D.; Kuszynski, C.A.; Joshi, S.S.; Pruess, H.G. Free radicals and grape seed proanthocyanidin extract: Importance in human health and disease prevention. Toxicology 2000, 148, 187-198. [CrossRef]

17. Shi, J.; Yu, J.; Pohorly, J.E.; Kakuda, Y. Polyphenolics in grape seeds-Biochemistry and functionality. J. Med. Food 2003, 6, 291-299. [CrossRef]

18. Guendez, R.; Kallithraka, S.; Makris, D.P.; Kefalas, P. Determination of low molecular weight polyphenolic constituents in grape (Vitis vinifera sp.) seed extracts: Correlation with antiradical activity. Food Chem. 2005, 89, 1-9. [CrossRef]

19. Travaglia, F.; Bordiga, M.; Locatelli, M.; Coisson, J.D.; Arlorio, M. Polymeric proanthocyanidins in skins and seeds of 37 Vitis vinifera L. cultivars: A methodological comparative study. J. Food Sci. 2011, 76, 742-749. [CrossRef]

20. Bagchi, D.; Swaroop, A.; Preuss, H.G.; Bagchi, M. Free radical scavenging, antioxidant and cancer chemoprevention by grape seed proanthocyanidin: An overview. Mutat. Res. 2014, 768, 69-73. [CrossRef]

21. Carpenter, R.; O'Grady, M.N.; O'Callaghan, Y.C.; O’Brien, N.M.; Kerry, J.P. Evaluation of the antioxidant potential of grape seed and bearberry extracts in raw and cooked pork. Meat Sci. 2007, 76, 604-640. [CrossRef] [PubMed]

22. Pacheco-Ordaz, R.; Wall-Medrano, A.; Goni, M.G.; Ramos-Clamont-Montfort, G.; Ayala-Zavala, J.F.; Gonzalez-Aguilar, G.A. Effect of phenolic compounds on the growth of selected probiotic and pathogenic bacteria. Lett. Appl. Microbiol. 2018, 66, 25-31. [CrossRef] [PubMed]

23. Bordiga, M.; Montella, R.; Travaglia, F.; Arlorio, M.; Coisson, J.D. Characterization of polyphenolic and oligosaccharidic fractions extracted from grape seeds followed by the evaluation of prebiotic activity related to oligosaccharides. Int. J. Food Sci. Technol. 2019, 54, 1283-1291. [CrossRef]

24. Falowo, A.B.; Foyemi, P.O.; Muchenje, V. Natural antioxidant against lipid-protein oxidative deterioration in meat and meat products: A review. Food Res. Int. 2014, 64, 171-181. [CrossRef]

25. Ruiz-Moyano, S.; Martin, A.; Benito, M.J.; Hernandez, A.; Casquete, R.; de Guia Cordoba, M. Application of Lactobacillus fermentum HL57 and Pedicoccus acidilactici SP979 as potential probiotics in the manufacture of traditional Iberian dry-fermented sausages. Food Microbiol. 2011, 28, 839-847. [CrossRef]

26. Jiang, J.; Xiong, Y.I. Natural antioxidants as food and feed additives to promote health benefits and quality of meat products: A review. Meat Sci. 2016, 120, 107-117. [CrossRef] 
27. Neffe-Skocińska, K.; Jaworska, D.; Kołożyn-Krajewska, D.; Dolatowski, Z.J.; Jachacz-Jówko, L. The effect of $\mathrm{LAB}$ as probiotic starter culture and green tea extract addition on dry fermented pork loins quality. BioMed Res. Int. 2015, 2015, 452757. [CrossRef]

28. Wójciak, K.M.; Libera, J.; Stasiak, D.M.; Kołożyn-Krajewska, D. Technological aspect of Lactobacillus acidophilus Bauer, Bifidobacterium animalis BB-12 and Lactobacillus rhamnosus LOCK900 use in dry-fermented pork neck and sausage. J. Food Proces. Preserv. 2017, 41, e12965. [CrossRef]

29. Kęska, P.; Stadnik, J.; Wójciak, K.M.; Neffe-Skocińska, K. Physico-chemical and proteolytic changes during cold storage of dry-cured pork loins with probiotic strains of LAB. Int. J. Food Sci. Technol. 2019. [CrossRef]

30. Aleksandrzak-Piekarczyk, T.; Koryszewska-Bagińska, A.; Bardowski, J. Genome sequence of the probiotic strain Lactobacillus rhamnosus (formerly Lactobacillus casei) LOCK900. Genome Announc. 2013, 1, e0640-13. [CrossRef]

31. Libera, J.; Kononiuk, A.; Kęska, P.; Wójciak, K.M. Use of grape seed extract as a natural antioxidant additive in dry-fermented pork neck technology. Biotechnol. Food Sci. 2018, 82, 141-150.

32. Commission Internationale de l'Eclairage (CIE). Supplement No. 2 to CIE Publication No. 15 Colorimetry; Bureau Central de la CIE: Paris, France, 1987.

33. Singleton, V.L.; Rossi, J. Colorimetry of total phenolics with phosphomolybdic-phosphotungstics acid reagents. Am. J. Enol. Vitic. 1965, 16, 144-158.

34. Re, R.; Pellegrini, N.; Proteggente, A.; Pannala, A.; Yang, M.; Rice-Evans, C. Antioxidant activity applying an improved ABTS radical cation decolorization assay. Free Radic. Biol. Med. 1999, 26, 1231-1237. [CrossRef]

35. International Organization for Standardization. ISO 15214. Microbiology of Food and Animal Feeding Stuffs-Horizontal Method for the Enumeration of Mesophilic Lactic Acid Bacteria-Colony-Count Technique at 30 ${ }^{\circ} \mathrm{C}$; ISO: Geneva, Switzerland, 1998.

36. International Organization for Standardization. ISO 21528-2. Microbiology of the Food Chain-Horizontal Method for the Detection and Enumeration of Enterobacteriaceae-Part 2: Colony-Count Technique; ISO: Geneva, Switzerland, 2017.

37. International Organization for Standardization. ISO 2917. Meat and Meat Products-Measurement of pH-Reference Method; ISO: Geneva, Switzerland, 1999.

38. Koniecko, E.S. Handbook for Meat Chemists; Avery Publishing Group, Inc.: Wayne, NJ, USA, 1979.

39. Malik, A.H.; Sharma, B.D. Use of hurdle techniques to maintain the quality of vacuum packed buffalo meat during ambient storage temperatures. Afr. J. Food Sci. 2011, 5, 626-636.

40. Pikul, J.; Leszczyński, D.E.; Kummerow, F.A. Evaluation of three modified TBA methods for measuring lipid oxidation in chicken meat. J. Agric. Food Chem. 1989, 37, 1309-1315. [CrossRef]

41. Baydar, N.G.; Sagdic, O.; Ozkan, G.; Cetin, S. Determination of antibacterial effects and total phenolic contents of grape (Vitis vinifera L.) seed extracts. Int. J. Food Sci. Technol. 2006, 41, 799-804. [CrossRef]

42. Jayaprakasha, G.K.; Selvi, T.; Sakariah, K.K. Antibacterial and antioxidant activities of grape (Vitis vinifera) seed extracts. Food Res. Int. 2003, 36, 117-122. [CrossRef]

43. Mayer, R.; Stecher, G.; Wuerzner, R.; Silva, R.C.; Sultana, T.; Trojer, L.; Feuerstein, I.; Krieg, C.; Abel, G.; Popp, M.; et al. Proanthocyanidins: Target compounds as antibacterial agents. J. Agric. Food Chem. 2008, 56, 6959-6966. [CrossRef]

44. Silvan, J.M.; Mingo, E.; Hidalgo, M.; De Pascual-Teresa, S.; Carrascosa, A.C.; Martinez-Rodriguez, A.J. Antibacterial activity of grape seed extract and its fractions against Campylobacter spp. Food Control 2013, 29, 25-31. [CrossRef]

(C) 2020 by the authors. Licensee MDPI, Basel, Switzerland. This article is an open access article distributed under the terms and conditions of the Creative Commons Attribution (CC BY) license (http://creativecommons.org/licenses/by/4.0/). 